\title{
PURE COLLAGEN CONE VERSUS COLLAGEN CONE BLENDED WITH GENTAMICIN IN ALVEOLAR RIDGE PRESERVATION FOLLOWING EXTRACTION OF CHRONIC INFECTED TOOTH A RANDOMIZED HISTOLOGICAL AND CLINICAL STUDY
}

\author{
Amr Mohammed Reda*, Hala Kamal Abd El Gaber**, \\ Shaimaa Mustafa Masloub Ali ${ }^{* * *}$ and Ahmed El Sayed Hamed Amr ${ }^{* * * *}$
}

\begin{abstract}
Aim: The present study was performed to evaluate effect of collagen cone blended with gentamicin and pure collagen cone in alveolar ridge preservation following extraction of tooth with chronic infection. Primary objective: Histological and histomorphometric evaluation of grafted bone. Secondary objective: Evaluation of changes in alveolar ridge dimensions radiographically and evaluation of primary implant stability

Subjects and Methods: Group (1): Ten extraction sockets where alveolar ridge preservation (ARP) was performed using collagen cone blended with gentamicin. Group (2): Ten extraction sockets where ARP was performed using pure collagen cone. Group (3): Ten extraction sockets where ARP was performed using xenograft and collagen membrane. Core biopsy performed during implant placement. Radiographic changes in buccolingual ridge width and alveolar crest were measured. Primary implant stability was evaluated.
\end{abstract}

Results: Significant difference in amount of new bone trabeculae between groups. Regarding radiographic buccolingual width, significant reduction in 3 groups after 5 months. Regarding percent changes of width, collagen/gentamicin was $-27,85 \pm 4,64$, collagen was $-42,50 \pm 5,29$ and xenograft was $-15,26 \pm 4,28$, the difference between groups was significant. Regarding intragroup radiographic ridge height changes significant reduction was noted in 3 groups after 5 months. Regarding percent decrease in radiographic height, collagen was $(-27.38 \pm 4,92)$, xenograft was $(-9.61 \pm 1,74)$ and collagen/gentamicin was $(-14,66 \pm 1,71)$. Difference between groups was significant. Non significant difference between collagen/gentamicin and xenograft implant stability was noticed.

Conclusion: Parasorb ${ }^{\circledR}$ cone genta showed more newly formed bone. Xenograft have best results regarding volumetric changes but decreased quality of newly formed bone compared with collagen/gentamicin.

\footnotetext{
* B.D.S, Faculty of Dentistry, Ain Shams University,2011.

** Professor of Oral Medicine, Periodontology and Oral Diagnosis Faculty of Dentistry, Ain-Shams University.

*** Lecturer of Oral pathology, Faculty of Dentistry, Ain Shams University.

**** Lecturer of Oral Medicine, Periodontology and Oral Diagnosis, Faculty of Dentistry, Ain Shams University.
} 


\section{INTRODUCTION}

During the treatment planning for dental implants, a prosthetic-driven protocol that results in implant placement in surgical positions with optimal implant restoration is recommended (F unato et al., 2007; Ishikawa et al., 2010; Levine et al., 2014). Adequate bone and soft tissue dimensions, good implant positioning in apico-coronal, mesio-distal and buccolingual dimensions and correct implant angulation are important factors in overall esthetic and functional success of dental implants (Buser \& Martin,2004; Funato et al., 2007 ; Ishikawa et al., 2010 ; Levine et al., 2014 ).There should be enough bone available to position dental implants in the correct mesio-distal dimension. The objective is to have a distance of at least $1.5 \mathrm{~mm}$ between natural teeth and dental implants and a distance of at least $3 \mathrm{~mm}$ between adjacent dental implants (Buser \& Martin, 2004). Available bone should also be present to position dental implants $1 \mathrm{~mm}$ palatally to an imaginary line at the point where adjacent teeth emerge at the implant site (Buser \& Martin, 2004).

Dental extraction is atraumatic procedure during which the soft tissue and hard tissue are disrupted. The periodontal ligament vascular structures are damaged, and the main periodontal ligament fibers are destroyed (Cardaropoli et al., 2003). The healing process after dental extraction is accompanied by bone loss which can prevent or make it difficult to place implants in prosthetically driven manner (Buser et al., 2004 ). Several studies have reported the dimensional and histological changes that occur in the alveolar process after tooth extraction (Schropp et al., 2003; Pietrokovski et al., 2007; Trombelli et al., 2008). Protocol of late implant placement has been challenged by many experiments and studies which aimed at decreasing the time needed for healing of dental socket after extraction before implant placement (Lazzara, 1989). Schwartz-Arard et al., 2000 assessed the survival rate of immediately placed dental implants after extraction and concluded that immediate implantation was a predictable surgical procedure. Despite the advantages of immediate implant placement, the entire bony walls around the implant cannot be completely preserved (Bhola et al., 2008), and in many cases the use of barrier membrane and bone graft is mandatory and may be accompanied by many complications (Rocchietta et al., 2008). Immediate implant placement is not preferred in some clinical situations like large sockets, buccal dehiscence, long roots and presence of acute infection (Becker et al.,1990 ; Whorle, 1998 ; Alves \& Neves, 2009).

The concept of alvolar ridge preservation (ARP) has been introduced to overcome limitations of immediate implantation. ARP is any procedure ranging from atraumatic extraction to the usage of any augmentation material that serves as scaffold for bone cells for better healing of extraction sockets (Patil et al., 2012).

Different alveolar ridge preservation techniques were proposed to maintain hard and soft tissue dimensions of extraction socket (Avila-Ortiz et al., 2014). When comparing spontaneous healing with using bone graft in extraction socket, the later proved to be more effective in maintaining ridge dimensions, although complete resorption prevention is not possible regardless of the biomaterials used (Carmagnola et al., 2003; Barone et al., 2008; Barone et al., 2013). The use of bone grafts and barrier membranes in ARP is accompanied with many problems. The amount of bone formation can be decreased due to the unpredictable resorption rate (Mcginnis et al., 1998). Moreover, when the barrier membranes are exposed or associated with inflammatory reactions in the adjacent tissue, the enzymatic activity of macrophages and neutrophils leads to a rapid degradation of the barrier membrane, thus decreasing barrier membrane integrity, barrier function and bone formation (Tatakis et al., 2000). The presence of infection in the grafted site associated with the acidic PH is accompanied 
by rapid rate of bone resorption and decreased bone formation (Yuan et al., 2001; Habibovic et al., 2006). Thus, infection of extraction socket that leads to acidic medium should be managed first before any grafting procedure to ensure good results and more bone formation (Misch, 1993). The mixture of bone graft and antibiotics has been evolved to overcome the problem of recipient site infection (Winkler et al., 2000).Use of local antibiotics necessitates the use of carriers or devices that maintain high concentration of antibiotics over a long period of time(Wachol-Drewek et al., 1996). Using collagen scaffolds loaded with antibiotics mainly gentamicin has been shown to decrease post-operative infection in extraction socket and accelerate wound healing (Yetim et al., 2010). Collagen sponge loaded with gentamicin proved to maintain high concentration of antibiotic together with its flexibility when compared to the rigid counterpart (Trafney et al., 1996). Collagen sponge not only present hemostatic properties but also minimize discomfort during the post-surgical period, stabilize blood clot and attract osteoblast to the grafted site (Atwood \& Coy, 1971). In a study by Natto et al., 2017, the combination of collagen sponge and allograft material resulted in less ridge resorption and maintainence of soft tissue quality and thickness. Collagen cones have been introduced for preservation of the architecture of extraction socket after dental extraction, the collagen cone is readily soaked with blood so increase the stability of blood clot leading to more soft and hard tissue formation together with perfect wound healing (Kim et al., 2015). Parasorb ${ }^{\circledR}$ cone genta consists of biologically absorbable equine type 1 collagen cone impregnated with gentamicin. In addition to the antibacterial properties of gentamicin the cone presents hemostatic action and stimulated wound healing (Harving et al., 1997).

Owing to the problems encountered with ARP in chronic infected sockets using bone graft and membranes, this study was performed to evaluate the use of gentamicin carried on collagen scaffold
(Parasorb ${ }^{\circledR}$ cone genta) in ARP in chronic infected sockets trying to introduce a new modality to avoid complications of bone graft and barrier membrane in such situations.

Aim of the study: The present study was performed to evaluate the effect of parasorb ${ }^{\circledR}$ cone genta and parasorb $₫$ cone in alveolar ridge preservation following extraction of tooth with a chronic infection. Primary objective: Histological and histomorphometric evaluation of the grafted bone. Secondry objective: Evaluation of changes in alveolar ridge dimensions radiographically and evaluation of primary implant stability clinically.

\section{SUBJECTS AND METHODS}

Patient selection: 30 patients were selected from the outpatient clinic of the department of Oral diagnosis, Oral medicine \& Periodontology, Faculty of Dentistry, Ain Shams University.

\section{Inclusion criteria:}

- Patients were free from any systemic disease as evidenced by Burket's oral medicine health history questionnaire. (Greenberg et al., 2012)

- Each patient required extraction of a non restorable premolar (or anterior tooth) with chronic infection located in maxilla and requested implant restoration.

- All patients should not have any known contraindication to oral surgery.

- Male or female with age range 20 - 40 years.

\section{Exclusion criteria:}

Smokers were excluded from our study. (keenan et al., 2016). Patients with poor oral hygiene, Patients with occlusal discrepancies and Pregnant females were excluded

\section{Patients grouping and treatment protocol:}

- All the patients received detailed written information about the treatment \& signed an informed detailed consent form. Preoperative analysis included patient history, medical 
history, clinical and radiographic examination at the first visit. Two weeks before the extraction (first surgery) professional debridement and instructions in self - preformed plaque control measures were delivered to all patients.

- 30 patients were randomly distributed by using sealed opaque envelopes into 3 groups:

Group 1(Test group): Ten extraction sockets where alveolar ridge preservation was performed using collagen cone blended with gentamicin (Parasorb® Cone Genta, RESORBA Medical, $\mathrm{GmbH}$, Germany). Figure (1)

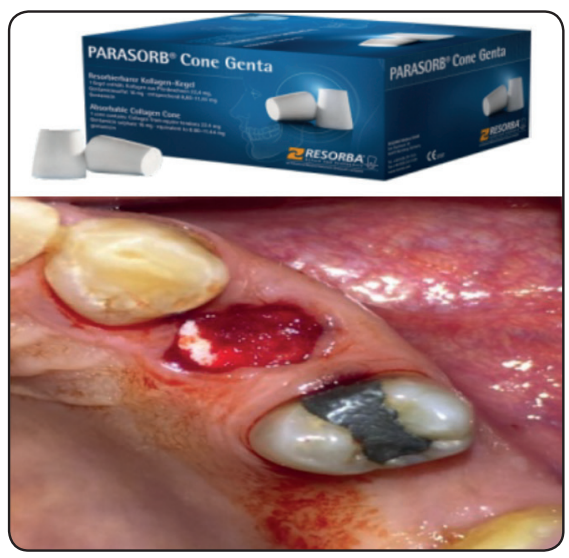

Fig. (1) : Ridge preservation using parasorb ${ }^{\circledR}$ cone genta

Group 2 (Test group): Ten extraction sockets where alveolar ridge preservation was performed using pure collagen cone (Parasorb® cone, RESORBA Medical, GmbH, Germany) Figure (2)

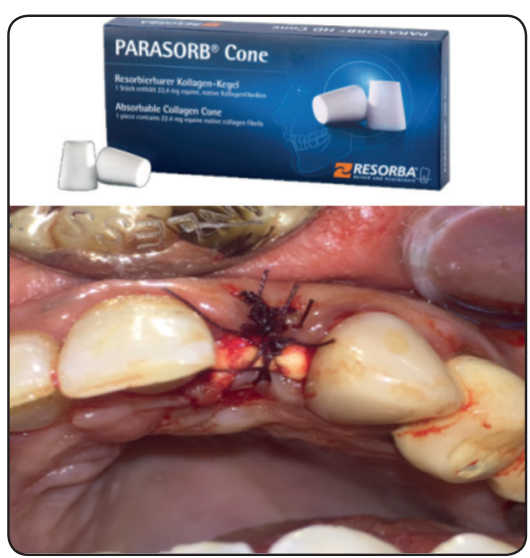

Fig. (2) : Ridge preservation using parasorb $₫$ cone
Group 3(Control group): Ten extraction sockets where alveolar ridge preservation was performed using Xenograft (Hypro oss, Bioimplon,Germany) and Collagen membrane (Hypro sorb, Bioimplon, Germany). Figure (3)

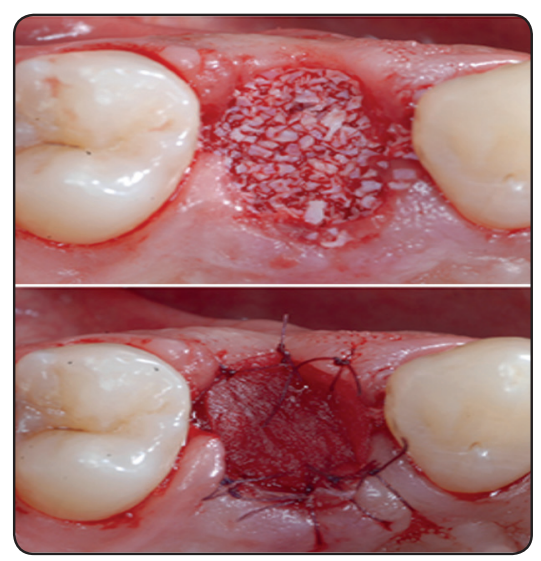

Fig. (3) : Ridge preservation using xenograft and collagen membrane

\section{Surgical procedures:}

- Two surgeries were carried out for each patient

- The first one involve atraumatic extraction under local anesthesia and alveolar ridge preservation (ARP) while the second (re-entry) surgery involve delayed implant placement in routine fashion and harvesting bone core biopsy for histological examination of the grafted bone. The second surgery was performed 5 months after the first one.

\section{1-Surgical procedures for alveolar ridge preservation}

\section{A) Atraumatic extraction:}

- Following local anesthesia atraumatic extraction using periotomes and forceps was performed, attempting to preserve the surrounding bone.

- The socket was curetted by bone curette to remove any soft tissue remnants then irrigation with chlorhexidine mouth wash $0.1 \%$. (Hexitol, arab drug company, Egypt)

- The buccal and lingual mucoperiosteum were slightly elevated in all groups around 4-5 mm 
occluso-apical using mucoperiosteal elevator creating buccal and lingual pouches without any vertical incisions to facilitate suturing and allow placing margins of barrier membrane in xenograft and barrier membrane group.

- Intraoperative clinical measures were performed.

\section{B) Alveolar ridge preservation:}

- In group 1 and 2 parasorb ${ }^{\circledR}$ cone genta, parasorb ${ }^{\circledR}$ cone was placed respectively into extraction socket then suturing with 4-0 polypropylene cross over suture.

- In group 3 xenograft is mixed with saline then placed in extraction socket then covered by collagen membrane where margins of the collagen membrane are placed below margins of buccal and palatal mucoperiosteum then stabilized by cross over 4-0 polypropylene sutures.

\section{C) Post - surgical medications and instructions:}

- Antibiotic : Amoxicillin - Clavulanic acid orally 1 gm every 12 hours for 7 days (Hibiotic,Amoun pharmaceutical, Egypt) + Metronidazole 500mg orally tab every 12 hours for 7 days (Amrizole, pharco pharmaceutical, Egypt). Anti - inflammatory: diclofenac potassium 50mg tab every 8 hours for 3 days (Cataflam, Novartis, Egypt) and anti - edematous: chymotrypsin - trypsin, 1 tablet 3 times daily for 3 days (Alphintern, Amoun pharmaceutical, Egypt)

- Patients were instructed to use chlorhexdine with concentration $0.1 \%$ ((Hexitol, arab drug company, Egypt) two times daily for one week starting the second day following the surgery to reduce risk of infection. (Drago et al., 2017)

- Patients were instructed to avoid any removable prosthesis during the five months healing period.

\section{D) Follow up visits:}

The patients returned for follow up and removal of suture 10 days later, patient follow up visits were scheduled every 1 month until the re-entry surgery.
2- Surgical procedures for bone core biopsy and implant placement ( $\operatorname{Re}$ - entry procedure):

- After 5 months from the grafting surgery, a re-entry procedure was performed in order to take bone core biopsy, and to place implants. Mucoperiosteal flaps were elevated to allow access to the alveolar ridges of involved sockets using crestal horizontal incision without vertical incisons.

- Core biopsy was taken from the grafted area. A trephine bur (2mm) (Hu-Friedy, USA) was used to obtain the bone biopsy from the implant site and was initially used before drilling for the implant.The bone biopsy was placed in $10 \%$ formalline for examination.

- An osteotomy site was prepared with the implant surgical kit (Neobiotech). The implants were inserted in the 3 groups. Mucoperiosteal flaps were always replaced and sutured with 4-0 polypropylene sutures. Four months later, prosthetic procedures were completed.

\section{Measurements and evaluations of the alveolar ridge}

\section{A-Clinical measurement:}

a- Implant primary stability: Following the final seating of the fixtures the smart peg is screwed to the fixture then stability of each implant was measured in ISQ units using the Ostell Mentor (Gothenburg, Sweden) at four points; buccal, palatal, mesial and distal. Then were averaged for each implant. Figure (4)

\section{b- Clinical alveolar ridge height changes:}

By using two standardized periodontal probes one horizontally on incisal edges of adjacent teeth and the other vertically at points located in each of the following sites: mid-buccal, mesial, distal and mid palatal crest of the ridge then the mean of measurements at each site was calculated. Alveolar ridge height was evaluated twice throughout the study. 


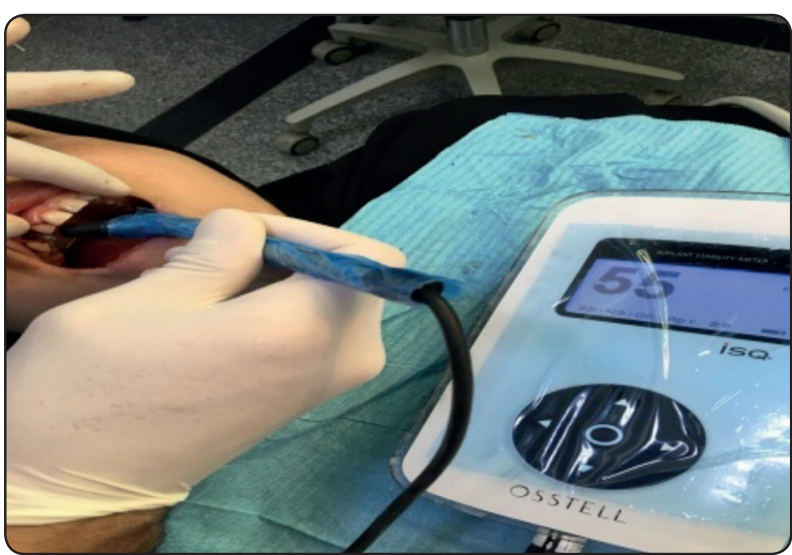

Fig. (4): Measurements of implant primary stability using ostell

1. Baseline: this was carried out during first surgery after extraction before the alveolar ridge preservation. Figure (5)

2. After $\mathbf{5}$ months: this was carried out during the re - entry surgery after flap elevation.

\section{B) Radiographic measurements:}

Cone beam computed tomography (CBCT) was used to assess the changes in the bucco-lingual width and height of the alveolar ridges.

\section{Two CBCTs were performed throughout the study}

1. The base line CBCT was taken two days before extraction.

2. The second CBCT was taken 5 months after alveolar ridge preservation and one week before implant placement.

\section{Radiographic alveolar ridge height and width measurements}

Radiographic alveolar ridge height was measured by selecting 3 sagittal sections at base line and measuring ridge height from fixed tangent at the base of anatomic structure (maxillary sinus or nasal floor) to the most coronal point of alveolar bone buccally and palataly and the mean was calculated. The same was then repeated after 5 months.

Radiographic alveolar ridge width was measured by selecting 3 sagittal sections at base line

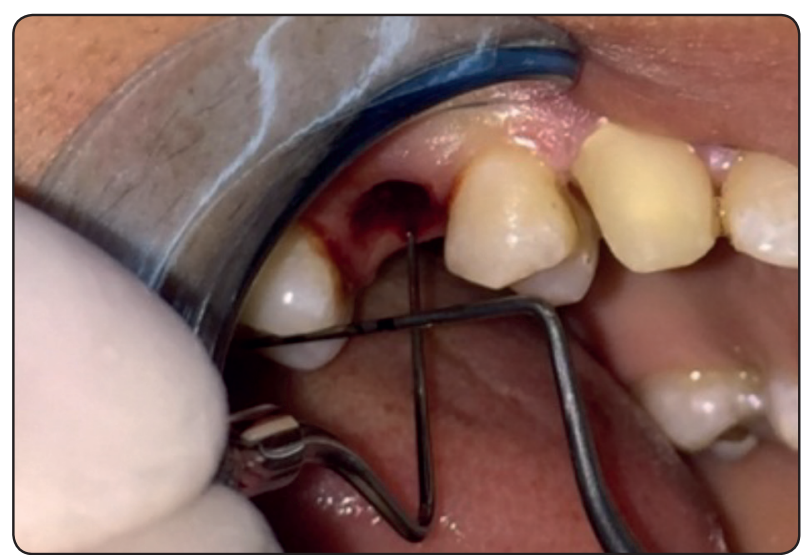

Fig. (5): Clinical alveolar ridge height measurements after extraction

and measuring buccolingual ridge width at 3 points $10,12,14 \mathrm{~mm}$ from crest at each section then the mean was calculated. The same was repeated after 5 months.

\section{Histological and histomorphometric evaluation:}

Histological evaluation of the grafted bone was performed by using bone core biopsy harvested at the reentry surgery for implant placement.

\section{a) Specimen staining procedure:}

Bone biopsy specimens obtained were fixed in $4 \%$ formalin and then decalcified in $17 \%$ nitric acid for 12 hours. Tissues were then embedded in paraffin wax and sectioned longitudinally into multiple 5-mm thick sections (the innermost section of each biopsy was used whenever possible Sections were then stained with Masson's Trichrome for qualitative and quantitative measurements of bone trabueculae and osteoid tissue. Other sections stained with hematoxylin and eosin (H\&E)

\section{b) Image analysis:}

For each MTC ( Masson's Trichrome) stained section, three microscopic fields showing the most abundant blue/purple staining (characteristic of the newly formed osteoid) were selected and photomicrographs were captured at original magnification of $20 X$. 
All images were captured using digital camera (EOS 650D, Cannon, Japan) which was mounted on a light microscope (BX60, Olympus, Japan). Images were then transferred to the computer system for analysis. This was performed in the Precision Measurement Unit, Oral Pathology Department, Faculty of Dentistry, Ain Shams University. All the steps of assessment were carried out using Image $\mathrm{J}$, $1.41 \mathrm{a}$, (NIH, USA) image analysis software.

Statistical analysis was then performed using a commercially available software program (SPSS 18; SPSS, Chicago, IL, USA).Values were presented as mean and standard deviation (SD) and confidence intervals. Data were explored for normality using Kolmogorov-Smirnov test of normality. For parametric data, ANOVA test was used for comparison between groups and was followed by Tukey's post hoc test if a significant difference was detected between groups. Paired (dependent) $\mathrm{t}$ test was used to compare before and after treatment values. Most values of percent change were non-parametric and were compared using Kruskall Wallis and Mann Whitney U test for intergroup comparisons. The percentage of change was calculated by the following formula:

$\frac{\text { Value after-value before }}{\text { Value before }} \times 100$

The level of significance was set at $\mathrm{P} \leq 0.05$.

\section{RESULTS}

\section{I- Histomorphometry:}

The highest mean value of newly formed bone trabeculae was recorded in parasorb ${ }^{\circledR}$ cone genta group, while the least value was in parasorb ${ }^{\circledR}$ group. ANOVA test revealed that the difference between groups was statistically significant $(\mathrm{p}=0.00)$. Tukey's post hoc test revealed a significant difference between each 2 groups (Table 1)

\section{II-Radiographic alveolar ridge buccolingual width:}

\section{A) Intergroup radiographic changes:}

At base line:the highest mean value was recorded in xenograft and barrier membrane group, while the least value was in parasorb ${ }^{\circledR}$ group. ANOVA test revealed that the difference between groups was statistically significant ( $\mathrm{p}=0.008$ ). Turkey's post hoc test revealed no significant difference between parasorb ${ }^{\circledR}$ cone genta and parasorb ${ }^{\circledR}$ groups (Table 2)

After 5 months:the highest mean value was recorded in xenograft and barrier membrane group, while the least value was in parasorb ${ }^{\circledR}$ group. ANOVA test revealed that the difference between groups was statistically significant $(\mathrm{p}=0.00)$. Tukey's post hoc test revealed a significant difference between each 2 groups (Table 2)

\section{B) Intragroup radiographic changes:}

Parasorb ${ }^{\circledR}$ cone genta group: The mean value significantly decreased after treatment $(\mathrm{P}=0.00)$.

Parasorb ${ }^{\circledR}$ group: The mean value significantly decreased after treatment $(\mathrm{P}=0.00)$.

Xenograft and barrier membrane group: The mean value significantly decreased after treatment $(\mathrm{P}=0.00)$.

\section{C) Intergroup comparison of percent change:}

The greatest percent decrease value was recorded in parasorb ${ }^{\circledR}$ group, while the least percent decrease was in xenograft and barrier membrane group. Kruskall Wallis test revealed that the difference between groups was statistically significant $(\mathrm{p}=0.000)$. Post hoc test revealed a significant difference between groups. (Table 3)

\section{III-Radiographic alveolar ridge height:}

\section{III-A-Intergroup radiographic changes:}

At base line: ANOVA test revealed that the difference between groups was not statistically significant $(\mathrm{p}=0.061)$ (Table 4) 
After 5 months: The highest mean value was recorded in parasorb ${ }^{\circledR}$ cone genta, while the least value was in parasorb ${ }^{\circledR}$ group. ANOVA test revealed that the difference between groups was statistically significant $(\mathrm{p}=0.022)$. Tukey's post hoc test revealed no significant difference between xenograft and barrier membrane group and parasorb (®) cone genta group (Table 4)

\section{III-B- Intragroup radiographic changes:}

Parasorb ${ }^{\circledR}$ cone genta group: The mean value significantly decreased after treatment $(\mathrm{P}=0.00)$.

Parasorb®group: The mean value significantly decreased after treatment $(\mathrm{P}=0.00)$.

Xenograft and barrier membrane group: The mean value significantly decreased after treatment $(\mathrm{P}=0.00)$.

\section{III-C-Intergroup comparison of percent change:}

The greatest percent decrease value was recorded in parasorb ${ }^{\circledR}$ group, while the least percent decrease was in xenograft and barrier membrane group. Kruskall Wallis test revealed that the difference between groups was statistically significant $(\mathrm{p}=0.000)$. Post hoc test revealed a significant difference between each 2 groups (Table 5)

\section{IV- Clinical alveolar ridge height:}

-Clinical alveolar ridge height was measured from incisal edge of neighbouring teeth to alveolar crest level and any numerical increase in value after 5 months mean crestal resorption and any decrease mean crestal augmentation.

\section{IV- A-Intergroup clinical changes}

At base line: The highest mean value was recorded in parasorb ${ }^{\circledR}$ cone genta group, while the least value was in parasorb ${ }^{\circledR}$ group. ANOVA test revealed that the difference between groups was not statistically significant $(\mathrm{p}=0.760)$, (Table 6)

After 5 months: The highest mean value was recorded in parasorb ${ }^{\circledR}$ group, while the least value was in xenograft graft and barrier membrane group. ANOVA test revealed that the difference between groups was statistically significant $(\mathrm{p}=0.001)$. Post hoc test revealed no significant difference between xenograft and barrier membrane group and parasorb (B) cone genta group (Table 6)

\section{IV-B-Intragroup clinical changes:}

Parasorb ${ }^{\circledR}$ cone genta group: The mean value significantly increased after treatment $(\mathrm{P}=0.00)$.

Parasorb ${ }^{\circledR}$ cone group: The mean value significantly increased after treatment $(\mathrm{P}=0.00)$.

Xenograft and barrier membrane group: The mean value significantly increased after treatment $(\mathrm{P}=0.00)$

IV-C-Intergroup Comparison of percent change: The greatest percent increase value was recorded in parasorb ${ }^{\circledR}$ group, while the least percent increase was in xenograft and barrier membrane group. Kruskall Wallis test revealed that the difference between groups was statistically significant $(\mathrm{p}=0.00)$. Post hoc test revealed no significant difference between parasorb ${ }^{\circledR}$ cone genta group and xenograft and barrier membrane group (Table 7)

\section{V- Implant primary stability:}

The highest mean value was recorded in xenograft and barrier membrane group, while the least value was in parasorb ${ }^{\circledR}$ group. ANOVA test revealed that the difference between groups was statistically significant $(\mathrm{p}=0.007)$. Tukey's post hoc test revealed no significant difference between xenograft and barrier membrane group and parasorb (

\section{VI- Histological Assessment:}

Masson's trichrome staining showed consistent results with hematoxylin and eosin staining after 5 months. On histological examination of parasorb ${ }^{\circledR}$ cone genta group: newly formed bone, both woven and mature lamellar bone was observed in all sites. Woven bone showed prominent osteoblastic rimming indicating the active bone formation process. Reversal lines were seen indicating bone remodeling. Also, prominent abundant osteocytes were observed entrapped in the lamellar bone 
which showed haversian systems (bony osteons). They were seen integrated and in continuity with the newly formed bone. The medullary spaces were seen also in continuity with the newly formed bone and filled with well vascularized connective tissue with prominent capillaries and abundant fibroblasts. Few inflammatory cell infiltrate was noticed in the medullary spaces.

On histological examination of parasorb (®) group: poorly formed bone trabeculae without osteoblastic rimming together with less mineralized tissue was found.

On histological examination of the xenograft and barrier membrane group: newly formed bone, both woven and mature lamellar types were observed in all sites. They contain plump of osteocyte in lacunae but they were not interconnecting with each other. Deeply stained areas were noticed representing incompletely resorbed residuals of the bone graft and incomplete continuity with the newly formed bone.

TABLE (1) Descriptive statistics and comparison of value of newly formed bone trabeculae between groups (ANOVA)

\begin{tabular}{|c|c|c|c|c|c|c|c|c|c|}
\hline \multirow{2}{*}{$\begin{array}{l}\text { Histomorphometric } \\
\text { analysis }\end{array}$} & \multirow{2}{*}{ Mean } & \multirow{2}{*}{$\begin{array}{l}\text { Std. } \\
\text { De }\end{array}$} & \multirow{2}{*}{$\begin{array}{l}\text { Std. } \\
\text { Error }\end{array}$} & \multicolumn{2}{|c|}{$\begin{array}{l}95 \% \text { Confidence } \\
\text { Interval for Mean }\end{array}$} & \multirow{2}{*}{ Min } & \multirow{2}{*}{ Max } & \multirow{2}{*}{$\mathrm{F}$} & \multirow{2}{*}{ Sig. } \\
\hline & & & & $\begin{array}{l}\text { Lower } \\
\text { Bound }\end{array}$ & $\begin{array}{l}\text { Upper } \\
\text { Bound }\end{array}$ & & & & \\
\hline Parasorb $®$ cone genta & $60.49^{\mathrm{a}}$ & 3.55 & 1.18 & 57.76 & 63.22 & 55.70 & 66.50 & 293.721 & $.000 *$ \\
\hline Parasorb ${ }^{\circledR}$ cone & $28.95^{\mathrm{c}}$ & 2.28 & .80 & 27.05 & 30.85 & 26.40 & 32.00 & & \\
\hline Xenograft and barrier membrane & $41.68^{\mathrm{b}}$ & 2.08 & .66 & 40.19 & 43.17 & 39.00 & 45.00 & & \\
\hline
\end{tabular}

Significance level $p \leq 0.05$, *significant Tukey's post hoc test: Sharing the same superscript letter within the same comparison means that the results are not significantly different.

TABLE (2) Descriptive statistics and comparison of radiographic alveolar buccolingual width between groups: (ANOVA)

\begin{tabular}{|c|c|c|c|c|c|c|c|c|c|c|}
\hline & & \multirow{2}{*}{ Mean } & \multirow{2}{*}{ Std. Dev } & \multirow{2}{*}{$\begin{array}{l}\text { Std. } \\
\text { Error }\end{array}$} & \multicolumn{2}{|c|}{$\begin{array}{l}95 \% \text { Confidence } \\
\text { Interval for Mean }\end{array}$} & \multirow{2}{*}{ Min } & \multirow{2}{*}{ Max } & \multirow{2}{*}{$\mathrm{F}$} & \multirow{2}{*}{ Sig. } \\
\hline & & & & & $\begin{array}{l}\text { Lower } \\
\text { Bound }\end{array}$ & $\begin{array}{l}\text { Upper } \\
\text { Bound }\end{array}$ & & & & \\
\hline \multirow{3}{*}{ 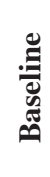 } & Parasorb ${ }^{\circledR}$ cone genta & $8.65^{\mathrm{b}}$ & .94 & .31 & 7.93 & 9.38 & 7.70 & 10.50 & 5.954 & $.008 *$ \\
\hline & Parasorb ${ }^{\circledR}$ cone & $8.61^{\mathrm{b}}$ & .89 & .31 & 7.87 & 9.36 & 7.00 & 9.50 & & \\
\hline & Xenograft and barrier membrane & $10.04^{\mathrm{a}}$ & 1.18 & .37 & 9.20 & 10.88 & 8.40 & 11.90 & & \\
\hline \multirow{3}{*}{ 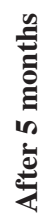 } & Parasorb ${ }^{\circledR}$ cone genta & $6.23^{\mathrm{b}}$ & .66 & .22 & 5.73 & 6.74 & 5.00 & 7.40 & 46.563 & $.000 *$ \\
\hline & Parasorb ${ }^{\circledR}$ & $4.94^{\mathrm{c}}$ & .56 & .20 & 4.47 & 5.41 & 4.00 & 6.00 & & \\
\hline & Xenograft and barrier membrane & $8.5^{\mathrm{a}}$ & 1.03 & .33 & 7.76 & 9.24 & 7.30 & 10.20 & & \\
\hline
\end{tabular}

Significance level $p \leq 0.05$, *significant, ns=non-significant Tukey's post hoc test: Sharing the same superscript letter within the same comparison means that the results are not significantly different 
TABLE (3) Descriptive statistics and comparison of radiographic alveolar buccolingual percent change between groups (Kruskall Wallis test)

\begin{tabular}{|c|c|c|c|c|c|c|c|c|c|}
\hline \multirow{2}{*}{$\begin{array}{l}\text { Percent } \\
\text { change }\end{array}$} & \multirow[t]{2}{*}{ Median } & \multirow{2}{*}{ Mean } & \multirow{2}{*}{$\begin{array}{l}\text { Std. } \\
\text { Dev }\end{array}$} & \multirow{2}{*}{$\begin{array}{l}\text { Std. } \\
\text { Error }\end{array}$} & \multicolumn{2}{|c|}{$\begin{array}{l}95 \% \text { Confidence } \\
\text { Interval for Mean }\end{array}$} & \multirow[t]{2}{*}{ Min } & \multirow[t]{2}{*}{$\operatorname{Max}$} & \multirow[t]{2}{*}{$\mathrm{P}$} \\
\hline & & & & & Lower & Upper & & & \\
\hline Parasorb ${ }^{\circledR}$ cone genta & -25.56 & $-27.85^{b}$ & 4.64 & 1.55 & -31.4 & -24.3 & -35.06 & -22.08 & $.000 *$ \\
\hline Parasorb ${ }^{\circledR}$ cone & -41.86 & $-42.50^{a}$ & 5.29 & 1.87 & -46.9 & -38.1 & -50.00 & -35.71 & \\
\hline Xenograft and membrane & -15.40 & $-15.26^{c}$ & 4.28 & 1.35 & -18.3 & -12.2 & -23.16 & -10.00 & \\
\hline
\end{tabular}

Significance level $p \leq 0.05$, *significant

Mann Whitney $U$ test: Sharing the same superscript letter within the same comparison means that the results are not significantly different.

TABLE (4) Descriptive statistics and comparison of radiographic alveolar ridge height between groups:(ANOVA)

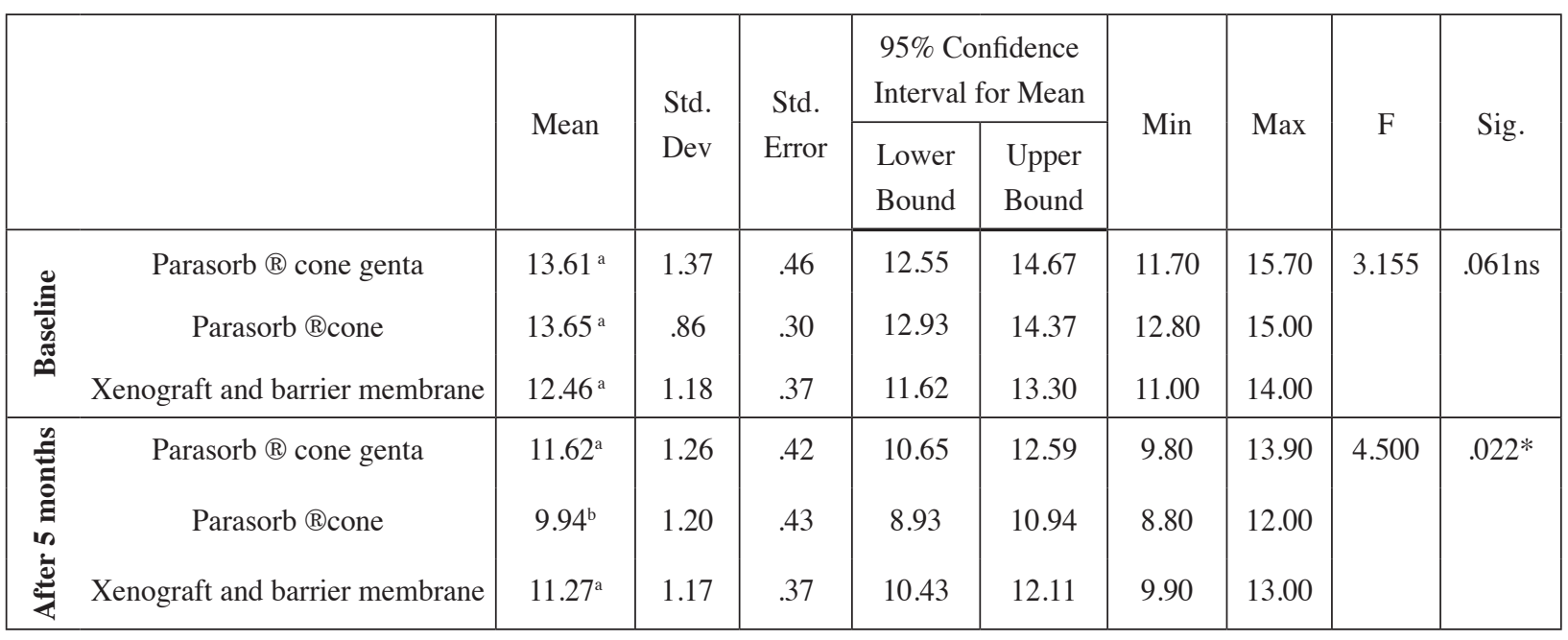

Significance level $p \leq 0.05$, *significant, ns=non-significant. Tukey's post hoc test: Sharing the same superscript letter within the same comparison means that the results are not significantly different.

TABLE (5) Descriptive statistics and comparison of radiographic alveolar ridge height percent changes between groups (Kruskall Wallis test)

\begin{tabular}{|c|c|c|c|c|c|c|c|c|c|}
\hline \multirow[t]{2}{*}{ Percent.change } & \multirow[b]{2}{*}{ Median } & \multirow[b]{2}{*}{ Mean } & \multirow{2}{*}{$\begin{array}{l}\text { Std. } \\
\text { Dev }\end{array}$} & \multirow{2}{*}{$\begin{array}{l}\text { Std. } \\
\text { Error }\end{array}$} & \multicolumn{2}{|c|}{$\begin{array}{l}95 \% \text { Confidence } \\
\text { Interval for Mean }\end{array}$} & \multirow[b]{2}{*}{ Min } & \multirow[b]{2}{*}{ Max } & \multirow[b]{2}{*}{$P$} \\
\hline & & & & & Lower & Upper & & & \\
\hline Parasrb ${ }^{\circledR}$ cone genta & -14.29 & $-14.66^{b}$ & 1.71 & .57 & -16 & -13.3 & -17.20 & -11.46 & $.000^{*}$ \\
\hline Parasorb $®$ cone & -29.02 & $-27.38^{a}$ & 4.92 & 1.74 & -31.5 & -23.3 & -33.33 & -20.00 & \\
\hline Xenograft and barrier membrane & -9.65 & $-9.61^{\mathrm{c}}$ & 1.74 & .55 & -10.9 & -8.4 & -13.04 & -7.14 & \\
\hline
\end{tabular}

Significance level $p \leq 0.05$, *significant Mann Whitney $U$ test: Sharing the same superscript letter within the same comparison means that the results are not significantly different. 
TABLE (6) Descriptive statistics and comparison of clinical alveolar ridge height between groups (ANOVA)

\begin{tabular}{|c|c|c|c|c|c|c|c|c|c|c|}
\hline & & \multirow{2}{*}{ Mean } & \multirow{2}{*}{ Std. De } & \multirow{2}{*}{$\begin{array}{l}\text { Std. } \\
\text { Error }\end{array}$} & \multicolumn{2}{|c|}{$\begin{array}{l}95 \% \text { Confidence } \\
\text { Interval for Mean }\end{array}$} & \multirow{2}{*}{ Min } & \multirow{2}{*}{ Max } & \multirow{2}{*}{$F$} & \multirow{2}{*}{ Sig. } \\
\hline & & & & & $\begin{array}{l}\text { Lower } \\
\text { Bound }\end{array}$ & $\begin{array}{l}\text { Upper } \\
\text { Bound }\end{array}$ & & & & \\
\hline \multirow{3}{*}{ 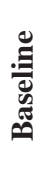 } & Parasorb ${ }^{\circledR}$ cone genta & 13.56 & 1.36 & .45 & 12.51 & 14.60 & 11.00 & 15.00 & .278 & $.760 \mathrm{~ns}$ \\
\hline & Parasorb $®$ cone & 13.13 & 1.25 & .44 & 12.08 & 14.17 & 11.00 & 15.00 & & \\
\hline & Xenograft and barrier membrane & 13.40 & .99 & .31 & 12.69 & 14.11 & 12.00 & 15.00 & & \\
\hline \multirow{3}{*}{ 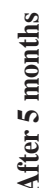 } & Parasorb ${ }^{\circledR}$ cone genta & $15.93^{\mathrm{b}}$ & 1.33 & .44 & 14.91 & 16.95 & 13.00 & 17.00 & 9.133 & $.001 *$ \\
\hline & Parasorb ${ }^{\circledR}$ cone & $17.41^{\mathrm{a}}$ & 1.07 & .38 & 16.52 & 18.31 & 15.70 & 19.00 & & \\
\hline & Xenograft and barrier membrane & $15.06^{\mathrm{b}}$ & 1.08 & .34 & 14.29 & 15.83 & 13.50 & 17.00 & & \\
\hline
\end{tabular}

Significance level $p \leq 0.05$, ns=non-significant,

Tukey's post hoc test: Sharing the same superscript letter within the same comparison means that the results are not significantly different.

TABLE (7) Descriptive statistics of clinical vertical bone percent changes between groups (Kruskall Wallis test)

\begin{tabular}{|c|c|c|c|c|c|c|c|c|c|}
\hline \multirow[t]{2}{*}{ Percent.change } & \multirow[t]{2}{*}{ Median } & \multirow[t]{2}{*}{ Mean } & \multirow{2}{*}{$\begin{array}{l}\text { Std. } \\
\text { Dev }\end{array}$} & \multirow{2}{*}{$\begin{array}{l}\text { Std. } \\
\text { Error }\end{array}$} & \multicolumn{2}{|c|}{$\begin{array}{l}\text { 95\% Confidence } \\
\text { Interval for Mean }\end{array}$} & \multirow[t]{2}{*}{ Min } & \multirow[t]{2}{*}{ Max } & \multirow[t]{2}{*}{$\mathrm{P}$} \\
\hline & & & & & Lower & Upper & & & \\
\hline Parasorb ${ }^{\circledR}$ cone genta & 17.24 & $17.84^{\mathrm{b}}$ & 6.01 & 2.00 & 13.21 & 22.46 & 11.11 & 27.69 & $0.00^{*}$ \\
\hline Parasorb ${ }^{\circledR}$ cone & 31.46 & $33.07^{\mathrm{a}}$ & 5.29 & 1.87 & 28.65 & 37.50 & 26.67 & 42.73 & \\
\hline Xenograft and barrier membrane & 12.40 & $12.47^{b}$ & 3.83 & 1.21 & 9.73 & 15.21 & 6.67 & 17.24 & \\
\hline
\end{tabular}

Significance level $p \leq 0.05$, *significant Mann Whitney U test: Sharing the same superscript letter within the same comparison means that the results are not significantly different.

TABLE (8) Descriptive statistics and comparison of primary stability results between groups (ANOVA)

\begin{tabular}{|c|c|c|c|c|c|c|c|c|c|}
\hline \multirow{2}{*}{ Primary stability results } & \multirow{2}{*}{ Mean } & \multirow{2}{*}{ Std. De } & \multirow{2}{*}{$\begin{array}{l}\text { Std. } \\
\text { Error }\end{array}$} & \multicolumn{2}{|c|}{$\begin{array}{l}95 \% \text { Confidence } \\
\text { Interval for Mean }\end{array}$} & \multirow{2}{*}{ Min } & \multirow{2}{*}{ Max } & \multirow{2}{*}{$\mathrm{F}$} & \multirow{2}{*}{ Sig. } \\
\hline & & & & $\begin{array}{l}\text { Lower } \\
\text { Bound }\end{array}$ & $\begin{array}{l}\text { Upper } \\
\text { Bound }\end{array}$ & & & & \\
\hline Parasorb $\AA$ cone genta & $60.7^{\mathrm{a}}$ & 6.05 & 2.02 & 56.05 & 65.35 & 52.00 & 68.30 & 6.207 & $.007 *$ \\
\hline Parasorb ${ }^{\circledR}$ cone & $53.81^{\mathrm{b}}$ & 3.25 & 1.15 & 51.09 & 56.53 & 50.00 & 57.80 & & \\
\hline Xenograft and barrier membrane & $61.55^{\mathrm{a}}$ & 5.01 & 1.58 & 57.97 & 65.13 & 55.00 & 68.80 & & \\
\hline
\end{tabular}




\section{DISCUSSION}

The concept of alveolar ridge preservation (ARP) utilizes different biomaterials to decrease bone and soft tissue loss of the alveolar ridge after tooth extraction (Cheng \&Fagd, 2016). Infection remains the most common complication to be encountered when bone graft and barrier membrane are used during alveolar ridge preservation. Absence of infection is mandatory because infection of the grafted site usually results in compromised healing and less bone regeneration. In severe cases, infection could result in loss of the whole grafting material and even resorption of the surrounding bone $(\boldsymbol{A h} \boldsymbol{h} \&$ Shin, 2008).In the present study, resorbable collagen cones blended with antibiotic were tested as a socket preservation material. Collagen is well known of its biocompatibility and ability of increasing wound healing. Further, the use of collagen barrier membranes in the field of guided bone regeneration has been extensively investigated and showed more successful results (Gentile et al., 2011). Collagen induces new bone formation through enhancement of proliferation, and survival of osteoblasts (Brodie et al., 2005).In previous study by Kim et al., 2017 new bone formation occurred in the space previously occupied by collagen plug. A complete bony tissue was observed after 5 months from using collagen plug as a socket preservation material and most of the immature bone had turned into lamellar bone.(Kim et al., 2017) Schnutenhauset al., 2018 concluded that sockets treated with collagen plug after extraction showed less bone resorption when compared to empty sockets which may be due to increased osteoblastic functions (Brodie et al., 2005). Parasorb ${ }^{\circledR}$ cone genta used in our study is a unique combination that consists of collagen and gentamicin that do not need primary closure due to the absence of bone substitute material. In the present study, none of the involved patients regarding parasorb ${ }^{\circledR}$ cone genta group developed postoperative infection. This may be due to the effect of gentamicin incorporated within the socket preservation material.
In our study implant placement and bone biopsy taking were done 5 months after extraction and ARP. According to study by Kotsakis et al., 2014, implant placement was done 5 months after extraction and ARP. It is generally accepted that formation of bone of adequate quality to accommodate a dental implant occurs 3 to 6 months following the grafting procedure which is in accordance with previous studies where re-entry surgery was done after 4-5 months from ARP with xenograft and barrier membrane (Renzo et al., 2017; Lai et al., 2019). Thus in our study implant placement after 5 months decrease probability of surgical intervention in non -bone-filled sockets and also allow time for resolution of any preexisting infection, and soft tissue healing (Demirel et al., 2003). Strict inclusion and exclusion criteria were used during patient selection to minimize the variables that may affect results.

Patients in our study were medically free in order to minimize any variable factors and to avoid any factors that may affect healing of the extraction socket and that increase liability to complication.

\section{(Mombelli et al., 2006)}

All patients in our study were nonsmokers because smoking is a risk factor in the process of alveolar ridge preservation and associated with poor results due to increased bone loss according to previous studies. (Lindfors et al., 2010; keenan et al., 2016)

Patients in the present study were limited to the age range 20 - 40 years to ensure good healing capacity and good patient cooperation (Akbar et al., 2018).Older patients were excluded since they have changes in physiological, pathological, and psychological conditions that may affect patient concern regarding the whole surgical procedure. Also, physical status acquired with age may affect oral hygiene procedures and overall healthcare (Rowe \& Kahn, 1987). Also, malnutrition is increased by age so a decline in functional status, immune impairment, poor wound healing and 
delayed recovery from surgery should be expected (Amarya et al., 2015).

Changes in estrogen and progesterone levels during pregnancy increase gingival inflammation through changes in chemotaxis and migration of inflammatory cells together with increased levels of cytokines and enzymes, thus pregnant females were excluded from our study (Wumin et al., 2015). In the current study, cone beam computed tomography $(\mathrm{CBCT})$ is used to evaluate bone width and height at the dental implant site. Also, CBCT help detecting bone defects such as dehiscence and fenestrations, as well as concavities in bone (Buser\& Martin, 2004). In our study all teeth extracted by atraumatic approach using periotoms and luxators as it preserves the hard and soft tissues around teeth, because the conventional extraction techniques either elevate the tooth by leveraging against the interproximal bone resulting in damage to the interproximal bone or use of forceps to luxate the tooth from its socket which often results in morphological changes of the socket. (Oghli et al., 2010)

ARP was performed using flapless approach that preserve soft and hard tissue. Authors reported that flapless approach results in less bone resorption when compared to ARP by flap elevation. (Fickl et al., 2008; Blanco et al., 2011).

Polypropylene suture was used in our study as it maintain tensile strength with no biodegradation, it has low friction so less tissue trauma during suturing, low tissue reactivity and less infection. (Gaspar et al., 1983)

The chlorhexidine was used in our study as an antibacterial agent before extraction, after extraction and curettage of the socket and after socket augmentation stage as it is the gold standard local antimicrobial agent in many previous studies. (Rolla \& Melsen, 1975; Woodcock, 1988 ; Kuyyakamond \& Quesnel, 1992). Patients were instructed to use chlorhexdine with concentration $0.1 \%$ two times daily for one week starting the second day following the surgery to reduce risk of infection. (Drago et al., 2017). Post - operative antibiotic after ARP procedure for period varying from three to ten days were recommended by previous studies (Sculean et al., 2001; Froum et al., 2015).

In our study histological examination and histomorphometry were performed to detect quantity of newly formed bone and quality of bone where implant was inserted which is a key factor in the process of osseointegration (Maimoun et al., 2010).

Regarding histological examination in our study different elements were of great importance to be examined. Woven bone that show prominent osteoblastic rimming indicated active bone formation process (Canfield et al.,2000). Osteocytes participate in the synthesis and mineralization of the osteoid matrix, but its main function is bone remodeling. Thus their presence in histological sections indicate mechanical loads variation a phenomena known as mechanotransduction. (Lanyon, 1993). The reversal lines between segments of bone that are formed at different times were noted in our histological sections which indicated bone remodeling. (Romano et al., 1997)

Histomorphometric analysis was performed in our study for additional informations regarding amount of newly formed bone per area fraction, where in parasorb ${ }^{\circledR}$ cone genta group the result was $60,49 \pm 3.55$, parasorb $₫$ group the result was $28,95 \pm 2,28$ and in xenograft and barrier membrane group the result was $41,68 \pm 2,08$ with statistical significant difference between groups. Which highlights the role that may be played with antibiotic.

Regarding radiographic alveolar ridge buccolingual width changes, significant reduction was noted in 3 groups after 5 months. This means decrease in bone width over time after extraction which is in agreement with previous reports that described that post extraction healing always characterized by osseous resorption especially in the horizontal plane of the residual alveolar ridge (Schropp et al., 2003). These changes may be 
limited but not avoided when grafting of the socket is used (Barone et al., 2008)

Regarding percent changes of radiographic alveolar ridge width, parasorb $(\AA)$ cone genta group was $-27,85 \pm 4,64$, parasorb ${ }^{\circledR}$ group was $-42,50 \pm 5,29$ and xenograft and barrier membrane group was $-15,26 \pm 4,28$, this means that greater percent changes was in parasorb ${ }^{\circledR}$ group followed by parasorb ${ }^{\circledR}$ cone genta group followed by xenograft and barrier membrane group with statistical significant difference between groups. The significantly less resorption noted in the bone graft and barrier membrane group may be related to the particulate bone graft which is biocompatible and osteoconductive(Wenz et al., 2001).These important biological properties allow the apposition of newly formed bone by osteoprogenitor cells and the partial remodeling by osteoclasts and osteoblasts of the host. Morever, the large interconnecting pore volume and its compostion encourage the formation and ingrowth of new bone at the implantation sites. (Accorsi-Mendoça et al., 2011).

Also, the presence of gentamicin aid in the prevention of postoperative infections and the treatment of any remaining pre - extraction infection through the local delivery of the antibiotic so decreasing amount of bone resorption in parasorb ${ }^{\circledR}$ cone genta group in comparison to parasorb ${ }^{\circledR}$ cone group. (Mezzomo et al., 2010).

Regarding alveolar ridge vertical changes, significant alveolar bone resorption in vertical height was noted in 3 groups after 5 months, both clinically (measurements from incisal edges of neighboring teeth to crest of the ridge) and radiographically (measurements from fixed land mark like maxillary sinus till crest of the ridge). This was in agreement with other reviews that showed that a certain degree of ridge height loss should be expected even if alveolar ridge preservation was done. (Horváth et al., 2013; Ortiz et al., 2014)

Regarding percent change of clinical alveolar ridge height, parasorb ${ }^{\circledR}$ cone genta group was
$17,84 \pm 6,01$, parasorb ${ }^{\circledR}$ group was $33.07 \pm 5,29$ and xenograft and barrier membrane group was $12,47 \pm 3,38$ this means that greater percent change (greater bone loss) was in parasorb ${ }^{\circledR}$ group followed by parasorb ${ }^{\circledR}$ cone genta group followed by xenograft and barrier membrane group with statistical significant difference between xenograft and barrier membrane group and parasorb ${ }^{\circledR}$ group. Finding no significant difference between xenograft and barrier membrane group and parasorb ${ }^{\circledR}$ cone genta group assure the positive role exerted by gentamicin when added to the collagen scaffold in competing existing chronic infection and minimizing resorption. (Raja et al., 2012)

Regarding implant primary stability, parasorb (B) cone genta group was $60,7 \pm 2.02$ and xenograft and barrier membrane group was $61,55 \pm 1,58$ with non statistical significant results between them and parasorb ${ }^{\circledR}$ group was $53,81 \pm 1,15$ with statistical significant difference between it and previous groups. But when considering the histological examination of regenerated bone for xenograft and barrier membrane group, deeply stained areas representing incompletely resorbed residuals of the bone graft were noticed and this was not noticed in the collagen cones histological sections which showed completely newly formed bone. Also, histomorphometric analysis showed greater newly formed bone per area fraction in parasorb $(\mathbb{B}$ cone genta group in comparsion to xenograft and barrier membrane group. Thus, inspite of similar primary stability between xenograft and barrier membrane group and parasorb ${ }^{\circledR}$ cone genta group, but different bone composition between groups may have an effect on the long term function of the dental implant. In our study, unfortunately implant stability after loading was not evaluated which should be considered in further similar studies.

Thus to conclude, xenograft and barrier membrane group showed best results regarding volumetric changes in ARP of chronic infected sockets but less quality of newly formed bone when compared with parasorb ${ }^{\circledR}$ cone genta group. 


\section{CONCLUSION}

- Parasorb ${ }^{\circledR}$ cone genta in alveolar ridge preservation showed completely newly formed bone and more newly formed bone per area fraction.

- Xenograft and barrier membrane have best results regarding volumetric changes in ARP of chronic infected sockets but decreased quality of newly formed bone when compared with parasorb ${ }^{\circledR}$ cone genta.

- Bone resorption after extraction cannot be avoided but can be minimized through alveolar ridge preservation (ARP).

\section{REFERENCES}

1. Accorsi-Mendoça T, Zambuzzi WF, Monteiro Bramante C, et al. Biological monitoring of xenomaterial for grafting: An evaluation in critical-sized calvarial defects. Journal of Materials Science: Materials in Medicine.;22:997-1004. 2011.

2. Ahn J - J, Shin H - I. Bone tissue formation in extraction sockets from sites with advanced periodontal disease: a histomorphometric study in humans. Int J Oral Maxillofac Implants: 23 (6): 1133-8. 2008

3. Alves CC, Neves M. Tapered implants: From indications to advantages. Int J Periodontics Restorative Dent ;29:1617. 2009.

4. Amarya, Shilpa, Kalyani Singh, and Manisha Sabharwal. "Changes during aging and their association with malnutrition.” Journal of Clinical Gerontology and Geriatrics 6.3 78-84. 2015.

5. Atwood DA, Coy WA. Clinical, cephalometric and densitometric study of reduction of residual ridges. J Prosthet Dent ;26:280-295. 1971.

6. Avila -Ortiz, G. Rodriguez JC, Rudek I, Benavides E, Rios H, Wang HL Effectiveness of Three Different Alveolar Ridge Preservation Techniques: A Pilot Randomized Controlled Trial. Int. J. Periodontics Restorative Dent. 2014

7. Barone A, Calvo Guirado JL, Covani U. Xenograft versus extraction alone for ridge preservation after tooth removal: a clinical and histomorphometric study. Journal of Periodontology. Aug;79 (8):1370-7. 93.2008.

8. Barone A, Ricci M, Tonelli P et al. Tissue changes of extraction sockets in humans: a comparison of spontaneous healing vs. ridge preservation with xenograft and secondary soft tissue healing. Clinical oral implants research. Nov;24(11):1231-7. 2013.

9. Becker W, Becker BE. Guided tissue regeneration for implants placed into extraction sockets and for implant dehiscences: surgical techniques and case report. Int JPeriodontics Restorative Dent;10:376-391.1990.

10. Blanco J, Liñares A, Pérez J, Muñoz F. Ridge alterations following flapless immediate implant placement with or without immediate loading. Part II: A histometric study in the Beagle dog. J Clin Periodontol ; 38: 762-770. 2011

11. Brodie, J. C., F., Sansac, C., Duffort, J.F. “Osteoblast interactions with calcium phosphate ceramics modified by coating with type I collagen.” Journal of Biomedical Materials Research Part A: An Official Journal of The Society for Biomaterials, The Japanese Society for Biomaterials, and The Australian Society for Biomaterials and the Korean Society for Biomaterials 73.4 409-421. 2005.

12. Buser D, Martin W, Belser UC. Optimizing esthetics for implant restorations in the anterior maxilla: anatomic and surgical considerations. Int J Oral Maxillofac Impl; 19(suppl): 43-61.2004.

13. Canfield AE, Doherty MJ, Ashton BA. Osteogenic potential of vascular pericytes. En: Davies JE ed. Bone Engineering. Toronto: Davies JE ed.; p. 143-51. 2000.

14. Cardaropoli G, Araújo M, Lindhe J. Dynamics of bone tissue formation in tooth extraction sites. An experimental study in dogs. J Clin Periodontol; 30:809-18.2003.

15. Carlsson GE, Bergman B, Hedegard B. Changes in contour of the maxillary alveolar process under immediate dentures. A longitudinal clinical and X - ray cephalometric study covering 5 years. Acta Odontol Scand; 25 (1): $45-75.1967$.

16. Carmagnola, Daniela, Patrick Adriaens, and Tord Berglundh. "Healing of human extraction sockets filled with Bio-Oss®®." Clinical oral implants research $14.2: 137-143.2003$

17. Chan JK "The wonderful colors of the hematoxylin-eosin stain in diagnostic surgical pathology". Int J Surg Pathol. 22 (1): 12-32. doi:10.1177/1066896913517939. PMID 24406626. 2014.

18. Cheng LL, Fagd DDS, Alveolar ridge preservation with bone graft may limit physiological ridge loss after tooth extraction. J Am Dent Assoc; 147 (3): 2046. Doi: 10. $1016 /$ j. adaj. 2015. 12. 015. 2016. 
19. Demirel, A. L. Erbil, H. Y., Avcı, Y., \& Mert, O.Delayed implant placement in comparison to immediate regarding presence of infection. Science, 299(5611), 1377-1380. 2003.

20. Drago, Lorenzo, Monica Bortolin, Silvio Taschieri, Elena De Vecchi, Serse Agrappi, Massimo Del Fabbro, Luca Francetti, and Roberto Mattina. "Erythritol/chlorhexidine combination reduces microbial biofilm and prevents its formation on titanium surfaces in vitro.” Journal of Oral Pathology \& Medicine 46, no. 8 : 625-631. 2017.

21. Fickl S, Zuhr O, Wachtel H, Bolz W, Huerzeler M. Tissue alterations after tooth extraction with and without surgical trauma: A volumetric study in the beagle dog. J Clin Periodontol ; 35: 356-363. 2008.

22. Froum, Stuart J., and Mea A. Weinberg. "An Evaluation of Antibiotic Use in Periodontal and Implant Practices." International Journal of Periodontics \& Restorative Dentistry 35 , no. 4.2015 .

23. Funato A, Salama M Ishikawa T, Garber DA, Salama H. Timing, positioning, and sequential staging in esthetic implant therapy: a four dimensional perspective. International Journal of Periodontics and Restorative Dentistry.; 27: 313-323. 2007.

24. Gaspar, MR, Movius, HJ, Rosental, JJ, Bell, DD, Lemire, GG, and Odou, M. Prolene sutures are not a significant factor in anastomotic false aneurysms. Am J Surg. ; 146: 216-219.1983

25. Gentile P, Chiono V, Tonda - Turo C, Ferreira AM, Ciardelli G. Polymeric membranes for guided bone regeneration. Biotechnol J; 6 (10): 118797 . Doi: 10. 1002 / biot. 201100294. 2011.

26. Greenberg BL, Glick M. Screening for unidentified increased systemic disease risk in a dental setting. American journal of public health. Jul;102(7): 10.2012

27. Habibovic, T.M. Sees, M.A. van den Doel, C.A. van Blitterswijk, K. de Groot, Osteoinduction by biomaterials physicochemical and structural influences, J.Biomed. Mater. Res. A 77 (4) 747-762. 2006.

28. Harving S, Hougaard K, Gottrup F, Kolmos HJ. [Gentacoll. A combined collagen - gentamicin preparation].Ugeskr; 159 (28): 4416-8. 1997.

29. Horváth A, Mardas N, Mezzomo LA, Needleman IG, Donos N. Alveolar ridge preservation. A systematic review. Clinical oral investigations. Mar 1;17(2):341-63. 2013.
30. Ipsen, P. Jorgenson, V. Damholt, G. Torholm, Acta Orthro Scand. 62 592..1991.

31. Ishikawa T, Salama M, Funato A, Kitajama H, Moroi H, et al. Three dimensional bone and soft tissue requirements for optimizing esthetic results in compromised cases with multiple implants. International Journal of Periodontics and Restorative Dentistry.; 30: 502-512. 2010.

32. Keenan JR, Veitz-Keenan A. The impact of smoking on failure rates, postoperative infection and marginal bone loss of dental implants. Evidence-based dentistry. Mar;17(1):4. 2016.

33. Kim, Dong-Min, et al. "Validity of collagen plugs for ridge preservation in a canine model." Implant dentistry 26.6 : 892-898. 2017.

34. Kim JS, Cha JK, Cho AR, et al. Acceleration of bone regeneration by BMP-2-loaded collagenated biphasic calcium phosphate in rabbit sinus. Clin Implant Dent Relat Res.; 17:1103-2015.

35. Kuyyakamond, T., Quesnel, L.B.,. The mechanism of action of chlorhexidine. FEMS Microbiology Letters 100, 211-215.1992.

36. Lai, Pin-Chuang, Diksha Katwal, and Henry Greenwell. "Allografts and Xenografts for PeriodontalPlastic Surgical Procedures." Current Oral Health Reports 6, no. 3 :218229. 2019

37. Lanyon L. Osteocytes, strain detection, bone remodeling and remodeling. Calcified Tissue Int;53:102-7. 1993.

38. Lazzara RJ: Immediate implant placement into extraction sites: surgical and restorative advantages. Int J Periodontics Restorative Dent;9:332-343. 1989.

39. Levine RA, Guy HB, Cochran DL. Soft tissue augmentation procedures for mucogingival defects in esthetic sites. International Journal of Oral Maxillofacial implants.; 29: 155-185.2014.

40. Lindfors LT, Tervonen EA, Sándor GK, Ylikontiola LP. Guided bone regeneration using a titanium-reinforced ePTFE membrane and particulate autogenous bone: the effect of smoking and membrane exposure. Oral Surgery, Oral Medicine, Oral Pathology, Oral Radiology, and Endodontology. Jun 1; 109(6):825-30. 2010

41. Lyons F, Partap S, O'Brien FJ. Part 1: scaffolds and surfaces. Technol Health Care.;16:305-17.2008. 
42. Mkubilius, R Kubilius, A Gleiznys. The preservation of alveolar bone ridge during tooth extraction. Stomatologija. ; 14(1):3-11. 2012.

43. Maimoun L, Brennan TC, Badoud I, Dubois - Ferriere V, Rizzoli R, Ammann P. Strontium ranelate improves implant osseointegration. Bone I: 46 (5): 1436-41. Doi: 10. $1016 /$ j. bone. 2010. 01. 379. 2010.

44. Mcginnis M, Larsen P, Miloro M, Beck M. Comparison of resorbable and nonresorbable guided bone regeneration materials: a preliminary study. In J Oral Maxillofac Implants,I3:30-5.1998.

45. Mezzomo L. Preservacao do rebordo alveolar: ensaic clinico randomizado e revisao sistematica da literatura. N.D.; (3): $35-77.2010$.

46. Misch CM. protocol to be followed when grafting chronic infected socket Pract Periodontics Aesthet Dent.;8:12735. 1993.

47. Mombelli A, Cionca N. Systemic diseases affecting osseointegration therapy. Clinical oral implants research.;17(S2):97-103. 2006

48. Natto, Z. S., Parashis, A., Steffensen, B., Ganguly, R., Finkelman, M. D., \& Jeong, Y. N. Efficacy of collagen matrix seal and collagen sponge on ridge preservation in combination with bone allograft: A randomized controlled clinical trial. Journal of clinical periodontology, 44(6), 649-659. 2017

49. Oghli AA, Steveling H. Ridge preservation following tooth extraction: A comparison between atraumatic extraction and socket seal surgery. Quintessence International.;41(7). 2010.

50. Ortiz, G., S. Elangovan, K. W. O. Kramer, D. Blanchette, and D. V. Dawson. "Effect of alveolar ridge preservation after tooth extraction: a systematic review and meta-analysis.” Journal of dental research 93, no. 10 : 950-958.2014.

51. Patil S, Rakhewar P, Doiphode : An unexampled epitome altering our profession J Dent Implant; 2 (2): 121 Doi: 10. 4103 / 0974-6781.102230.2012.

52. Pietrokovski J, Starinsky R, Arensburg B, Kaffe I. Morphologic characteristics of bony edentulous jaws. J Prosthodont 16: 141-147. 2007.

53. Renzo, G., S. Ippoliti, S. Luigi, D. A. Francesca, and D. C. Stefano. "Tissue Dimensional Chang-es Following Alveolar Ridge Preservation with Different Xenografts Associated with a Collagen Mem-brane. Results at the 4-Month
Re-Entry Surgery." Int Arch Oral Maxillofac Surg 1, no. 003.2017.

54. Rocchietta I, Fontana F, Simion M. Clinical outcomes of vertical bone augmentation to enable dental implant placement. A systematic review. J Clin Periodontol; 35(8 Suppl): 203-15. 2008.

55. Rolla, G, \& Melsen, B. On the mechanism of plaque inhibition by chlorhexidine. Journal of Dental Research 54, Special Issue B. 57-62.1975.

56. Romano, P. R., J. G. Caton, and J. E. Puzas. "The reversal line may be a key modulator of osteoblast function: observations from an alveolar bone wound-healing model." Journal of periodontal research 32.1 143-147.1997.

57. Rowe J.W. , R.L. Kahn Human aging: usual and successful Science, 237 pp. 143-149.1987.

58. Schropp L, Kostopoulos L, Wenzel A. Bone healing following immediately versus delayed placement of titanium implants into extraction sockets: a prospective clinical study. Int J Implants Oral Maxillofac; 18 (2): 189-99. 2003.

59. Schwartz - Arad D, Grossman Y, Chaushtu G. The Clinical Effectiveness of Implants Placed Immediately Into Fresh Extraction Sites of Molar Teeth. JPeriodontol; 71 (5): 83944. Doi: 10. 1902 / jop. 2000. 71. 5. 839. 2000.

60. Schnutenhaus, Sigmar, et al. "Alveolar ridge preservation with a collagen material: a randomized controlled trial." Journal of periodontal \& implant science 48.4 236-250. 2018.

61. Sculean, Anton, Anja Blaes, Nicole Arweiler, Elmar Reich, Nikolaos Donos, and Michel Brecx. "The effect of postsurgical antibiotics on the healing of intrabony defects following treatment with enamel matrix proteins." Journal of Periodontology 72, no. (2): 190-195. 2001.

62. Tatakis D, Promsudthi A, Wikesjo U. Devices for periodontal regeneration. Periodontol; 19: 59-73. 2000.

63. Trafney, M. Stepinska, M. Antos, J. Grzybowski, Antimicrob Agents Chem. 39 2645. 1995.

64. Trombelli L, Farina R, Marzola A, Bozzi L, Liljenberg B, Lindhe J. Modeling and remodeling of human extraction sockets. J Clin Periodontol: 35: 630-639. 2008. WacholDrewek, M. Pfeiffer, E. Scholl.biomaterials.171733.1996.

65. Wenz B, Oesch B, Horst M. Analysis of the risk of transmitting bovine spongiform encephalopathy though bone grafts derived from bovine bone. Biomaterials.;22:1599-1606.2001. 
66. Whorle PS: Single-tooth replacement in the aesthetic zone with immediate provisionalization: Fourteen consecutive case reports. Pract Periodontics Aesth Dent 10:1107. 1998.

67. Winkler H., O. Janata, C. Berger, W. Wein, and A. Georgopoulos, "In vitro release of vancomycin and tobramycin from impregnated human and bovine bone grafts," Journal of Antimicrobial Chemotherapy, vol.46, no.3, pp.423428.2000

68. Woodcook,P.M. Bisguanides as industrial biocides.Critical Reports in Applied Chemistry.23, 19.1988.

69. Wumin, Shao-Wu Chen, and Shao-Yun Jiang. "Relation- ship between gingival inflammation and pregnancy." Mediators of inflammation .2015.

70. Yetim I, Ozkan O V, Dervisoglu a, Erzurumlu K, Canbolant E. Effect of local gentamicin application on healing and wound infection in patients with modified radical mastectomy: a prospective randomized study, J Int Med Res; 38 (4): 1442-7.2010.

71. Yuan, J.D. De Bruijn, Y. Li, J. Feng, Z. Yang, K. De Groot, $\mathrm{X}$. Zhang, Bone formation induced by calcium phosphate ceramics in soft tissue of dogs: a comparative study between porous alpha-TCP and beta-TCP, J.Mater. Sci.Mater.Med. 12 (1) 7-13. 2001. 